\title{
CZYNNOŚCI MAJĄCE NA CELU OBEJŚCIE USTAWY NA TLE ORZECZNICTWA SĄDÓW POLSKICH*
}

\section{WSTĘP}

W doktrynie dominuje stanowisko, zgodnie z którym czynności prawne mające na celu obejście ustawy stanowią kategorię czynności prawnych sprzecznych z ustawą ${ }^{1}$. W orzecznictwie sądów polskich pogląd ten nie został w pełni przejęty. W niektórych orzeczeniach, szczególnie tych wydanych w ciagu ostatnich 30 lat, sądy odróżniły obejście prawa od innych konstrukcji prawnych, w tym od sprzeczności z prawem. Ta rozbieżność w opiniach zachęca do rozważenia: (II) definicji obejścia prawa, (III) przesłanek stwierdzenia obejścia prawa, (IV) przykładów czynności prawnych mających na celu obejście ustawy, (V.2) kwestii autonomiczności konstrukcji obejścia prawa oraz (V.3) funkcji pełnionych przez regulację zakazu dokonywania czynności prawnych mających na celu obejście ustawy w orzecznictwie sądów polskich.

\section{DEFINICJE OBEJŚCIA USTAWY W ORZECZNICTWIE SĄDÓW POLSKICH}

Kodeks cywilny nie zawiera definicji legalnej czynności mających na celu obejście ustawy. Także $\mathrm{w}$ orzecznictwie nie wypracowano definicji obejścia prawa - sądy odwołuja się do trzech definicji sformułowanych w doktrynie.

W orzecznictwie Sądu Najwyższego i sądów apelacyjnych najczęściej przywoływana jest definicja zaproponowana przez Zbigniewa Radwańskiego (oparta na definicji sformułowanej przez Aleksandra Woltera), zgodnie z która „przez czynność prawna podjętą w celu obejścia ustawy rozumie się czynność wprawdzie nieobjętą zakazem prawnym, ale przedsięwziętą w celu osiagnięcia

* Tekst ten powstał na podstawie referatu wygłoszonego w ramach seminarium Katedry Prawa Cywilnego, Handlowego i Ubezpieczeniowego na Wydziale Prawa i Administracji Uniwersytetu im. Adama Mickiewicza w Poznaniu. Uczestnikom spotkania bardzo dziękuję za uwagi i krytykę, które starałam się uwzględnić w obecnej wersji tekstu. Bardzo dziękuję dr Joannie Kruszyńskiej-Koli za komentarz i krytykę tekstu.

${ }^{1}$ Terminy „sprzeczność z ustawą” i „,sprzeczność z prawem”, jak i „obejście ustawy” i „obejście prawa” używane są zamiennie. Przez „prawo" i „ustawę” autor rozumie uregulowane w przepisach prawnych normy bezwzględnie wiążące i semiiperatywne. 
skutku zakazanego przez prawo"2. Tę definicję uzupełniono w orzecznictwie o następujące wyjaśnienia: „Ujmując sprawę z pewnym uproszczeniem należy stwierdzić, że obejście ustawy to zachowanie podmiotu prawa, który napotykając prawny zakaz dokonania określonej czynności prawnej, »obchodzi" go w ten sposób, że dokonuje innej niezakazanej formalnie czynności w celu osiagnięcia skutku związanego z czynnością zakazana, a tym samym sprzecznego z prawem"3. W orzecznictwie podkreślono formalną niesprzeczność z ustawa, jak również pozór zgodności czynności prawnej z ustawą ${ }^{4}$ Ponadto sądy wielokrotnie wskazywały, że obejście prawa ma na celu ,wywołanie skutku sprzecznego z prawem" .

Sąd Najwyższy i sądy apelacyjne tylko kilkakrotnie użyły alternatywnych definicji. Zgodnie z definicja zaproponowana przez Wojciecha Wasowicza, obejście prawa prowadzi do zniweczenia „sensu norm bezwzględnie obowiąujących o znacznej ogólności ujęcia"6. Autor postuluje, żeby traktować obejście ustawy jako klauzulę generalna. Klauzula ta „[z]akazuje osiagania w drodze dokonywania czynności prawnych rezultatów, które są niemożliwe do pogodzenia nie z zakazami i nakazami przepisów ustawy, lecz z pozaprawnymi regułami słuszności czy sprawiedliwości”. Sąd Najwyższy tylko dwukrotnie - w 2005 i 2006 r. - powołał się na definicję zaproponowana przez Wassowicza (cytując jednocześnie definicję sformułowaną przez Woltera i Radwańskiego) ${ }^{8}$.

Nawiązanie do definicji zaproponowanej przez Tadeusza Zielińskiego można odnaleźć w jednym z orzeczeń Wojewódzkiego Sądu Administracyjnego w Warszawie. Mianowicie, sąd ten uznał, że „[o]bejście prawa oznacza, że wszystkie czynności dokonane przez strony sa jawne, a skutki przez nie wywołane - pożądane, jedynie cel ich dokonania jest sprzeczny z ustawa”" Wydaje się, że definicja ta opiera się na zaproponowanym przez Zielińskiego założeniu, że „możliwa jest właśnie sytuacja, w której wola wewnętrzna skierowana jest na wywołanie skutku niedozwolonego, a przejaw woli na osiagnięcie skutku prawem przewidzianego. Jeżeli więc treścią czynności prawnej jest znaczenie przejawionej woli, to w przedstawionej sytuacji mamy do czynienia z czynnościa zgodna z ustawa, jakkolwiek wola wewnętrzna ma za cel skutek zabroniony" ${ }^{\prime \prime}$.

W literaturze przedmiotu można znaleźć jeszcze czwarta definicję obejścia prawa. Roman Trzaskowski proponuje, żeby rozumieć obejście prawa jako

${ }^{2}$ Radwański, Trzaskowski (2019): 311; Wolter (2001): 318.

${ }^{3}$ Wyrok SN z 9 sierpnia 2005 r., III UK 89/05, Lex nr 182780.

${ }^{4}$ Np. wyroki SN: z 6 października 2004 r., I PK 545/03, Lex nr 166553; z 25 listopada 2004 r., I PK 42/04, Lex nr 151294.

${ }^{5}$ Wyrok SN z 25 listopada 2004 r., I PK 42/04.

${ }^{6}$ Wasowicz (1999): 83.

${ }^{7}$ Wasowicz (1999): 93.

8 Wyroki SN: z 5 października 2005 r., I UK 32/05, Lex nr 191088; z 28 marca 2006 r., I UK 228/05, Lex nr 957386.

${ }^{9}$ Wyrok WSA w Warszawie z 30 maja 2005 r., III SA/Wa 1/05, Lex nr 171389.

${ }^{10}$ Zieliński (1967): 78-79. 
czynność prawna, której treść i akt dokonania nie są bezpośrednio sprzeczne z prawem, ale której strony „świadomie zmierzają do wywołania rezultatu, któremu miała zapobiec obchodzona norma"11. Ta definicja nie została dotąd wspomniana w orzecznictwie SN.

\section{PRZESŁANKI STWIERDZENIA OBEJŚCIA PRAWA}

W literaturze przedmiotu przyjmuje się, że elementami charakterystycznymi dla obejścia prawa w prawie prywatnym sa: „(1) istnienie wyraźnej normy prawnej zakazującej osiagania określonego celu; (2) dokonanie czynności prawnej prowadzącej do osiagnięcia takiego celu zakazanego przez normę prawną o charakterze iuris cogentis; [i] (3) ustalenie, że sama dokonana czynność prawna jest zgodna z prawem"12.

Jarosław Grykiel i Maciej Lemkowski proponują ponadto uwzględnienie $\mathrm{w}$ analizie czynności prawnej badania stanów podmiotowych. Postuluja oni rozpoczęcie takiego badania czynności prawnej od analizy jej skutków (rezultatów). Stwierdzenie, że są one przez prawo zabronione, umożliwia przejście do analizy ich znaczenia, polegającej na rozważeniu, „czy dokonanie kwestionowanej czynności prawnej podjęte zostało wyłącznie lub głównie w celu osiagnięcia owego skutku, czy też stał się on jedynie swego rodzaju ubocznym rezultatem tej czynności, której jednak pierwszoplanowym celem było coś zupełnie innego" ${ }^{13}$. Zdaniem autorów ustalenie znaczenia rezultatu czynności nie jest możliwe bez zbadania woli i zamiaru stron tej czynności, które można ustalić także przez zastosowanie domniemań faktycznych ${ }^{14}$.

Analiza dotychczasowego orzecznictwa SN i sądów apelacyjnych pozwala na sformułowanie podobnego testu. Zgodnie z proponowanym testem, stwierdzenie obejścia ustawy wymaga pozytywnych odpowiedzi na cztery następujace pytania: (I) czy dokonanie kwestionowanej czynności prawnej nie jest zakazane? (II) czy dokonanie czynności prawnej sprzecznej z prawem prowadziłoby do takiego samego rezultatu, do jakiego prowadzi dokonanie kwestionowanej czynności prawnej? (III) czy nie istnieje inne racjonalne uzasadnienie potwierdzające konieczność dokonania kwestionowanej czynności prawnej? (IV) czy co najmniej jedna ze stron kwestionowanej czynności prawnej miała zamiar osiagnięcia tego rezultatu?

\section{Brak zakazu dokonania kwestionowanej czynności prawnej}

Udzielenie odpowiedzi na pytanie, czy dokonana czynność prawna nie jest zakazana, wymaga stwierdzenia, że treść lub cel kwestionowanej czynności

11 Trzaskowski (2014): 441.

12 Wyrok TK z 11 maja 2004 r., K 4/03, Dz. U. 2004, Nr 122, poz. 1288. Zob. Vidal (1957): $121-164$.

13 Grykiel, Lemkowski (2010): 53.

${ }^{14}$ Grykiel, Lemkowski (2010): 53. 
prawnej nie jest wprost sprzeczny z prawem ani z zasadami współżycia społecznego ${ }^{15}$.

Czynności mające na celu obejście ustawy są tak ukształtowane, że zgodnie z językowymi regułami interpretacyjnymi nie są one objęte zakresem normowania normy prawnej. Przełamanie znaczenia językowego, będące rezultatem wykładni systemowej lub funkcjonalnej, mogłoby być kwestionowane w przypadkach czynności mających na celu obejście ustawy. W tych przypadkach bowiem dotyczyłoby to jednoznacznego językowo przepisu przyznającego uprawnienia obywatelom albo modyfikujacego przepis centralny. W wielu przypadkach zastosowanie wykładni rozszerzajacej byłoby sprzeczne z zasada że wyjątków nie należy interpretować rozszerzająco ${ }^{16}$. Także zastosowanie analogia legis mogłoby być uznane za niedopuszczalne, jeżeli powodowałaby szczególnie ujemne skutki dla stron czynności prawnej, np. przez ograniczenie ich $\operatorname{praw}^{17}$.

\section{Rezultat dokonania kwestionowanej czynności prawnej}

Ustalenie celu dokonywanej czynności prawnej jest niezbędnym kryterium oceny, czy dana czynność służy obejściu ustawy ${ }^{18}$. W prakseologii „cel” określa się jako „przyszły stan”, przy czym dokładność charakteryzowania i sposób przejścia „od stanu aktualnego do owego przyszłego stanu na ogół nie [sa] jednoznacznie określone"19. Przyszły stan jest zamierzony przez podmiot dokonujący czynności prawnej i jest jednym z rezultatów czynności prawnej.

Cel czynności prawnej mającej na celu obejście ustawy często określany jest jako „zakazany”20. Może być to mylące, obejście prawa zachodzi bowiem nie wtedy, gdy obowiąuje norma prawna wprost zakazujacca osiagnięcia określonego stanu przyszłego, ale wtedy gdy wykładnia przepisu prowadzi do wniosku, że „cel ustawy można osiagnaćc wyłącznie przez dokonanie czynności prawnej odpowiadającej treści normy prawnej” ${ }^{21}$, a strony dokonały innej czynności prawnej.

Dokonanie czynności prawnej musi stworzyć stronom tej czynności teoretyczną możliwość osiagnięcia przyszłego stanu (rezultatu) świadczącego o obejściu ustawy ${ }^{22}$. Konieczne jest hipotetyczne ustalenie, że dokonanie czynności prawnej sprzecznej z prawem prowadziłoby do takiego samego rezultatu, do jakiego prowadzi dokonanie kwestionowanej czynności prawnej. Rezultat ten jednak osiaga się przez uniknięcie „zakazów, nakazów lub obciążeń

${ }_{15}$ Np. wyroki SN: z 25 lutego 2004 r., II CK 34/03, Lex nr 174159; z 9 sierpnia 2005 r., III UK 89/05; z 23 lutego 2006 r., II CSK 101/05, Lex nr 180197.

${ }^{16}$ Zieliński, Radwański (2006): 30; Morawski (2011): 193, 198-201, 202-207.

${ }^{17}$ Morawski (2011): 228.

${ }_{18}$ Wyrok SA w Gdańsku z 6 lipca 2016 r., III AUa 357/16, Lex nr 2157832. Tak też np. Safjan (2018): 298. Zob. Tracz, Zoll (1996): 71-75.

${ }^{19}$ Wawrzyńczak (1985): 58.

${ }^{20}$ Np. wyrok TK z 11 maja 2004 r., K 4/03.

${ }^{21}$ Radwański, Trzaskowski (2019): 313.

${ }^{22}$ Wyrok SN z 2 grudnia 2011 r., III PK 28/11, Lex nr 1163947; Safjan (2018): 298. 
wynikających z przepisu ustawy", a więc przez dokonanie czynności prawnej nieobjętej zakresem normowania normy obchodzonej ${ }^{23}$. Innymi słowy, dokonana czynność prawna prowadzi do wystapienia rezultatu, któremu norma prawna, zakazująca albo nakazująca dokonanie określonej czynności prawnej, ma na celu zapobiec.

W orzecznictwie i w literaturze przedmiotu wielokrotnie podnoszono, że czynność prawna mająca na celu obejście ustawy jest czynnością sprzeczną z ustawa, prowadzi bowiem do skutku zakazanego przez prawo ${ }^{24}$, i to także wtedy, gdy zakaz uzyskania określnego rezultatu nie jest wprost wypowiedziany w przepisie prawnym, ale zrekonstruowany w drodze wykładni ${ }^{25}$. Uważam, że jeżeli norma prawna nakazuje albo zakazuje określonym podmiotom w określonych okolicznościach określone zachowanie i naruszeniu tej normy można w drodze wykładni przyporządkować określone skutki - to nie oznacza to, że osiagnięcie każdego z tych skutków przez zachowanie wykraczające poza zakres normowania tej normy jest zawsze sprzeczne z prawem. Dokonanie jakiejkolwiek czynności prawnej wywołuje wiele skutków, których wyczerpujące określenie, chociażby ze względu na ich częściową nieprzewidywalność, nie jest możliwe. Dlatego wniosek, że każdy skutek czynności prawnej naruszającej ustawę jest zakazany przez prawo, byłby trudny do zaakceptowania. To oznacza, że czynność z ustawą niesprzeczna może spowodować też skutki, które wywołałaby czynność sprzeczna z ustawa. Dlatego to, że czynność sprzeczna z prawem i czynność mająca na celu obejście ustawy prowadzą do takiego samego skutku, nie oznacza, że obejście prawa jest formą sprzeczności z prawem.

Analiza orzecznictwa wykazuje, że o obejściu prawa można mówić tylko wtedy, kiedy osiagnięty rezultat nie jest typowym skutkiem dokonanej czynności prawnej ${ }^{26}$. Sąd Najwyższy słusznie uznał, że obejście prawa nie zachodzi, jeżeli rezultat osiagnięty przez dokonanie czynności prawnej jest zgodny z ustawą. O takim rezultacie możemy mówić, między innymi, jeżeli ustawa wprost określa skutki dokonania określonej czynności prawnej. Wniosek ten został wyartykułowany w orzeczeniach wydanych po 2004 r., w kontekście umów o pracę zawieranych w celu nabycia prawa do świadczeń z ubezpieczenia społecznego ${ }^{27}$. Trzeba jednak zauważyć, że osiagnięcie nietypowego rezultatu nie zawsze oznacza, że mamy do czynienia z obejściem prawa. Skutek niezamierzony przez ustawodawcę nie musi bowiem być skutkiem przez niego zakazanym.

Do stwierdzenie obejścia ustawy konieczna jest identyfikacja przepisu ustawy, którego naruszenie prowadziłoby do skutku jednocześnie będącego

${ }^{23}$ Wyrok SN z 11 stycznia 2006 r., II UK 51/05, Lex nr 214284. Zob. też Brzeziński (2004): 8; Kalinowski (2004): 307; Stawecki (2003): 88-89.

${ }^{24}$ Np. uchwała pełnego składu Izby Cywilnej SN z 19 grudnia 1972 r., III CZP 57/71, Lex nr 1468; tak też np. wyroki SN: z 25 lutego 2004 r., II CK 34/03; z 23 lutego 2006 r., II CSK 101/05; z 2 grudnia 2011 r., III PK 28/11; Dmowski, Rudnicki (2011): 281; Księżak (2014): 659.

${ }_{25}$ Tak też Stawecki (2003): 91.

${ }^{26}$ Np. wyrok SN z 18 kwietnia 2013 r., II CSK 557/12, Lex nr 1425320. Porównaj Grzybowski (1974): 513; Tracz, Zoll (1996): 73.

${ }^{27}$ Np. wyroki SN: z 25 listopada 2004 r., I PK 42/04; z 25 stycznia 2005 r., II UK 141/04, Lex nr 152390; z 28 kwietnia 2005 r., I UK 236/04, Lex nr 166474. 
skutkiem kwestionowanej czynności prawnej (norma obchodzona) ${ }^{28}$. „Obchodzone" przepisy muszą mieć charakter przepisów iuris cogentis ${ }^{29}$ albo - jak wynika z nowszego orzecznictwa - iuris semidispositivi ${ }^{30}$. Moga to być przepisy zarówno prawa prywatnego, jak i prawa publicznego ${ }^{31}$.

\section{Racjonalne uzasadnienie potwierdzające konieczność dokonania czynności prawnej}

Negatywną przesłanką stwierdzenia, że dokonana czynność prawna ma na celu obejście prawa, jest ustalenie istnienia racjonalnego uzasadnienia potwierdzającego konieczność dokonania kwestionowanej czynności prawnej.

W art. 58 Kodeksu cywilnego (k.c.) mowa jest o czynności prawnej „mającej na celu obejście ustawy", a nie czynności, w wyniku której dochodzi do obejścia ustawy. Dlatego uważam, że jeżeli dokonana czynność prawna miała inny cel niż obejście prawa, to wykluczona jest możliwość stwierdzenia obejścia ustawy. W tych przypadkach rezultat obejścia prawa jest jedynie „efektem ubocznym" dokonania czynności prawnej, a nie jej celem. Do tego samego wniosku można też dojść na podstawie analizy orzecznictwa dotyczącego ważności długoletnich umów o pracę na czas określony. Sąd Najwyższy wielokrotnie wskazywał, że zatrudnienie pracownika na podstawie takiej umowy o pracę może być działaniem zmierzającym do obejścia prawa, a w szczególności przepisów o ochronie zatrudnienia zawartych w art. $25^{1}$, 30 i 38 Kodeksu pracy (k.p.). Obejście prawa jednak nie zachodzi, jeżeli zatrudnienie pracownika na podstawie tej umowy jest rzeczowo usprawiedliwione ${ }^{32}$ przez wskazanie istnienia uzasadnionej lub racjonalnej przesłanki ${ }^{33}$, np. interesu obu stron ${ }^{34}$ czy rodzaju i charakteru świadczonej pracy (interwencyjny charakter pracy) ${ }^{35}$.

Tylko w części orzeczeń, w których stwierdzono wystapienie obejścia prawa, rozważano alternatywne uzasadnienie dokonania kwestionowanej czynności prawnej. Uważam, że rozważenie istnienia racjonalnego uzasadnienia dokonania czynności prawnej w każdym stanie faktycznym, w którym rozpatrywana jest możliwość obejścia prawa, pozwoliłoby na zobiektywizowanie procesu stwierdzania obejścia prawa. Określenie stanu świadomości i zamiaru stron

28 Wyrok SN z 23 lipca 1998 r., I PKN 245/98, Lex nr 37036. Tak też np. wyroki SN: z 23 września 1998 r., II UKN 229/98, Lex nr 37516; z 13 lipca 2000 r., II UKN 636/99, Lex nr 49985. Zob. Kalinowski (2001): 79-80; por. Trzaskowski (2002): 151-152.

29 Wyrok SA w Lublinie z 20 stycznia 1999 r., I ACa 377/98, Apelacja. Orzecznictwo Sądów Apelacyjnych. Sąd Apelacyjny w Lublinie 1999, nr 1, poz. C-2; wyroki SN: z 13 września 2001 r., IV CKN 381/00, Lex nr 49698; z 30 listopada 2005 r., I UK 61/05, Lex nr 607105.

${ }^{30}$ Wyrok SN z 23 lutego 2006 r., II CSK 101/05. Tak też np. wyroki SN: z 2 grudnia 2011 r., III PK 28/11; wyrok SN z 28 kwietnia 2016 r., I UK 156/15, Lex nr 2051472. W literaturze wspomina się tylko normy o charakterze iuris cogentis, np. Kalinowski (2001): 78; Brzeziński (2004): 8.

31 Wyroki SN: z 13 września 2001 r., IV CKN 381/00; z 23 lutego 2006 r., II CSK 101/05. Zobacz też uchwała SN z 9 marca 1993 r., III CZP 27/93, Lex nr 13281. Por. Trzaskowski (2002): 145-146.

32 Uchwała 7 sędziów SN z 16 kwietnia 1998 r., III ZP 52/97, Lex nr 32575.

${ }^{33}$ Wyrok SN z 7 września 2005 r., II PK 294/04, Lex nr 188092; tak też np. wyrok SN z 27 maja 2014 r., II PK 225/13, Lex nr 1511138.

34 Uchwała 7 sędziów SN z 16 kwietnia 1998 r., III ZP 52/97.

35 Wyrok SN z 19 listopada 1997 r., I PKN 390/97, Lex nr 33484. 
często nastręcza dużych trudności. Wykluczenie obejścia prawa już na podstawie istnienia uzasadnionej przesłanki dokonania kwestionowanej czynności pozwoliłoby na eliminację konieczności rozważania stanów podmiotowych stron.

Niemniej akceptacja tej przesłanki kreuje i jednocześnie legitymizuje sytuację, w której dwie czynności prawne mające taki sam rezultat, ze względu na istnienie albo brak istnienia racjonalnej przesłanki ich dokonania, moga być różnie zakwalifikowane (jako mające na celu obejście prawa i jako niemajace takiego celu). Ponadto przyjęcie konieczności wskazania istnienia uzasadnienia dokonania kwestionowanej czynności prawnej spowodowałoby akceptację swoistego domniemania, że jeżeli czynność prawna zmierza do osiagnięcia rezultatu, który jest typowym rezultatem innej, sprzecznej z prawem czynności prawnej, to jest to czynność mająca na celu obejście prawa. Dla zachowania ważności czynności jej strony musiałyby wykazać, że istnieje uzasadniona przesłanka dokonania kwestionowanej czynności.

\section{Zamiar uzyskania rezultatu, w wyniku którego dochodzi do obejścia ustawy}

Cel czynności prawnej, a więc uzyskanie rezultatu, w wyniku którego dochodzi do obejścia ustawy, musi być objęte świadomością wszystkich stron czynności $^{36}$ i zamiarem przynajmniej jednej z nich ${ }^{37}$. Czynność mająca na celu obejście prawa nie może bowiem być dokonana przypadkowo ${ }^{38}$.

Mimo że stan świadomości czy wiedzy stron czynności prawnej nie zawsze jest omawiany w orzecznictwie dotyczącym obejścia prawa, nie ulega wątpliwości, że strona nieświadoma czy też nieposiadajacca stosownej wiedzy nie może uformować zamiaru. Podkreślił to SN w postanowieniu z 2014 r., w którym wskazał na konieczność rozważenia: „czy strony umowy [...] miały dostateczną wiedzę prawnicza, aby z pełnym rozeznaniem posługiwać się tak szczegółowymi i skomplikowanymi konstrukcjami [prowadzącymi do rezultatu, w wyniku którego dochodzi do obejścia ustawy] [...]. Tylko zaś wykazanie, że strony tych umów miały wykształcenie prawnicze lub korzystały przy ich zawieraniu z usług fachowego doradcy, mogłoby uzasadniać przypisanie im świadomego działania w celu obejścia prawa"39.

W orzecznictwie uznano zamiar obejścia prawa przez co najmniej jedna ze stron za przesłankę niezbędną do stwierdzenia obejśsia ustawy ${ }^{40}$. Jak orzekł SN w 2008 r., zamiar stron można ustalić na podstawie stanu faktycznego sprawy ${ }^{41}$.

36 Np. wyrok SN z 18 kwietnia 2013 r., II CSK 557/12; postanowienie SN z 14 lutego 2014 r., II CSK 216/13, Lex nr 1458819.

37 Np. wyroki SN: z 23 lutego 2006 r., II CSK 101/05; z 1 czerwca 2010 r., II UK 34/10, Lex nr 619639; z 2 grudnia 2011 r., III PK 28/11.

38 Postanowienie SN z 14 lutego 2014 r., II CSK 216/13.

39 Postanowienie SN z 14 lutego 2014 r., II CSK 216/13.

${ }^{40}$ Np. wyroki SN: z 11 stycznia 2006 r., II UK 51/05; z 2 lipca 2008 r., II UK 334/07, Lex nr 531865; z 9 lutego 2012 r., I UK 265/11, Lex nr 1169836; z 28 kwietnia 2016 r., I UK 156/15. Odmienne Janas (2017): 496.

${ }^{41}$ Wyrok SN z 7 marca 2008 r., III CSK 317/07, Lex nr 385585. 
Ponadto realizacja czynności prawnej nie jest konieczna do stwierdzenia spełnienia przesłanki zamiaru obejścia prawa ${ }^{42}$.

Wątpliwości mogą dotyczyć jedynie tego, czy jeżeli tylko jedna strona ma zamiar obejścia prawa, to czy pozostałe strony czynności prawnej, a więc te niemające zamiaru obejścia prawa, muszą być świadome tego zamiaru. Zgodnie z uchwała pełnego składu Izby Cywilnej SN z 1972 r., „,[n]ie może być uważany za cel czynności prawnej ukryty zamiar, jaki jedna ze stron pragnie zrealizować przez wykonanie tej czynności, jeżeli druga strona tego zamiaru nie zna i go nie aprobuje" ${ }^{43}$. Odmienne stanowisko zają jednak SN w 2002 r., omawiajac znaczenie celu w kontekście artykułu $353^{1}$ k.c. - stwierdził, że „[c]el umowy nie musi natomiast być celem wspólnym dla obu stron, wystarczy, że do jego osiagnnięcia dąży jedna ze stron umowy, a druga jest tego świadoma lub - biorąc pod uwagę okoliczności zawarcia umowy oraz jej treść - powinna być świadoma" ${ }^{4}$. Stanowisko to wydaje się uzasadnione, jeżeli uwzględni się, że w proponowanym teście analiza świadomości i zamiaru stron zachodzi tylko wtedy, gdy strony nie wykazały istnienia uzasadnionej przesłanki dokonania kwestionowanej czynności prawnej. Jeżeli taka przesłanka nie istnieje, to występuje wysokie - graniczące z pewnością - prawdopodobieństwo, że druga strona czynności była świadoma celu czynności prawnej.

Zgodnie z orzeczeniem SN z 2005 r. sam zamiar obejścia prawa u strony czynności prawnej nie jest decydujący dla stwierdzenia, że czynność prawna ma na celu obejście ustawy ${ }^{45}$.

\section{PRZYKŁADY OBEJŚCIA USTAWY W ORZECZNICTWIE SĄDÓW POLSKICH}

Sądy konsekwentnie uznają pewne czynności prawne za dokonane w celu obejścia ustawy. Dotyczy to na przykład zawarcia umowy pożyczki połączonej z ustanowieniem hipoteki zwykłej na nieruchomości obciążonej prawem pierwokupu na rzecz podmiotu wskazanego w art. 599 § 2 k.c. i przeniesienie własności tej nieruchomości na pożyczkodawcę, by obejść bezwzględnie obowiązujące przepisy przewidujące prawo pierwokupu (np. na podstawie art. 10 ust. 5 ustawy z 16 kwietnia 2004 r. o ochronie przyrody) ${ }^{46}$. Stwierdzenie obejścia prawa $\mathrm{w}$ tych przypadkach zależy od braku istnienia racjonalnego uzasadnienia potwierdzającego konieczność dokonania czynności prawnej oraz od stwierdzenia świadomości i zamiaru obejścia prawa u stron tej czynności.

${ }^{42}$ Wyrok SN z 14 marca 2013 r., I UK 509/12, Lex nr 1555231.

${ }^{43}$ Uchwała pełnego składu Izby Cywilnej SN z 19 grudnia 1972 r., III CZP 57/71; tak też np. wyrok SN z 25 lutego 2004 r., II CK 34/03.

${ }_{44}$ Wyrok SN z 26 marca 2002 r., III CKN 801/00, Lex nr 54490. Tak też np. wyrok SN z 20 marca 2014 r., II CSK 290/13, Lex nr 1455196. Odmiennie np. Gutowski (2007): 1025; Machnikowski (2013): 520; Janiak (2012): 346.

45 Wyrok SN z 30 listopada 2005 r., I UK 61/05.

${ }^{46}$ Wyrok SN z 7 marca 2008 r., III CSK 317/07; zob. też postanowienie SN z 14 lutego 2014 r., II CSK 216/13. 
Należy jednak zauważyć, że niektóre czynności prawne zakwalifikowane w orzecznictwie sądowym jako służące obejściu prawa nie spełniały przesłanek czynności prawnej mającej na celu obejście ustawy. Można tu wyróżnić dwie grupy orzeczeń. Do pierwszej z nich należą orzeczenia, w których czynności prawne majace na celu osiagnięcie rezultatu wskazanego w ustawie uznano za obejście prawa. Na przykład do 2004 r. zawarcie umowy o pracę przez kobietę w ciąży w celu uzyskania świadczeń z ubezpieczenia społecznego uznawane było za obejście przepisów o ubezpieczeniu społecznym ${ }^{47}$. Do drugiej grupy należą orzeczenia, w których kwestionowana czynność prawna była pozorna, niezgodna z ustawą czy zasadami współżycia społecznego. Dotyczy to na przykład orzeczeń, w których rozważano legalność zawarcia z pracownikiem umowy cywilnoprawnej zobowiąującej pracownika do pracy tego samego rodzaju, co określona w umowie o pracę, ponad ustalony w umowie o pracę czas pracy ${ }^{48}$. Sąd Najwyższy uznał, że umowa ta miała na celu obejście przepisów dotyczących pracy w godzinach nadliczbowych, w szczególności art. 151, 178 i $203 \S 1$ k.p. oraz art. 4 ust. 1 ustawy z 25 listopada 1986 r. o organizacji i finansowaniu ubezpieczeń społecznych ${ }^{49}$. Jednakże zgodnie z wyrażoną w art. $18 \S 1 \mathrm{k} . \mathrm{p}$. zasadą uprzywilejowania pracownika „[p]ostanowienia umów o pracę oraz innych aktów, na których podstawie powstaje stosunek pracy, nie mogą być mniej korzystne dla pracownika niż przepisy prawa pracy". Takie postanowienia, zgodnie z $§ 2$ tego przepisu, są nieważne. Jeżeli więc umowa cywilnoprawna, kwalifikowana jako umowa uzupełniająca umowę o pracę, zobowiązuje pracownika do pracy w godzinach nadliczbowych w innych okolicznościach, niż jest to dopuszczone w art. $151 \S 1$ k.p., za wynagrodzenie niższe niż obliczone na podstawie art. $151^{1} \mathrm{k}$.p. albo jest sprzeczna $\mathrm{z}$ uregulowanym w art. 178 i 203 k.p. zakazem pracy określonych grup pracowników w godzinach nadliczbowych i porze nocnej, to oznacza to, że postanowienia tej umowy sa mniej korzystne dla pracownika niż przepisy prawa pracy, a tym samym, zgodnie z art. $18 \S 1$ i 2 k.p., sprzeczne z prawem i nieważne ${ }^{50}$.

\section{WNIOSKI KOŃCOWE}

\section{Analiza definicji i przesłanek obejścia prawa}

Przykłady z praktyki orzeczniczej wskazują na konieczność wystapienia wszystkich ze wskazanych przesłanek, aby stwierdzić obejście prawa ${ }^{51}$. Pewna wątpliwość mogłaby jednak powstać co do kolejności zastosowania przesłanek

${ }^{47}$ Np. wyroki SN: z 21 kwietnia 2004 r., II UK 314/03, Lex nr 585795; z 19 września 2003 r., II UK 41/03, Lex nr 106867; zob. też np. postanowienie SN z 14 stycznia 2008 r., II UK 232/07, Lex nr 864133.

48 Np. wyroki SN: z 17 kwietnia 2009 r., I UK 314/08, Lex nr 621571; z 19 stycznia 2010 r., I UK 261/09, Lex nr 577825; z 15 stycznia 2013 r., I UK 443/12, Lex nr 1308052.

${ }_{49}$ Wyrok SN z 16 grudnia 1998 r., II UKN 392/98, Lex nr 39059.

50 Tak też np. wyrok SN z 15 września 2006 r., I PK 80/06, Lex nr 326427.

${ }^{51}$ Np. wyrok SN z 7 marca 2008 r., III CSK 317/07; postanowienie SN z 14 lutego 2014 r., II CSK 216/13. 
istnienia uzasadnionego (racjonalnego) usprawiedliwienia potwierdzającego konieczność dokonania czynności prawnej i zamiaru oraz świadomości stron czynności prawnej. W orzeczeniach często najpierw rozważany jest stan świadomości i zamiar obejścia ustawy, a dopiero potem istnienie alternatywnych przesłanek dokonania kwestionowanej czynności. Należy zauważyć, że łatwiej ustalić istnienie lub brak istnienia alternatywnych przesłanek potwierdzających konieczność dokonania czynności prawnej, niż określić, często na podstawie okoliczności dokonania czynności i dokumentów towarzyszących jej dokonaniu, świadomość i zamiar stron czynności prawnej. Dlatego, moim zdaniem, dopiero po wykluczeniu istnienia racjonalnych przesłanek należy ustalić świadomość i zamiar stron czynności prawnej. Istnienie alternatywnych przesłanek eliminuje bowiem wtedy konieczność rozważenia stanów podmiotowych stron. Natomiast brak istnienia takiej przesłanki może stanowić jedną z okoliczności faktycznych pozwalających na stwierdzenie istnienia zamiaru lub świadomości obejścia prawa. Niewątpliwie zastosowanie omówionych przesłanek w każdym stanie faktycznym, w którym rozważane jest obejście prawa, pozwoliłoby na eliminacje orzeczeń, w których obejście prawa stwierdzono na podstawie potocznego rozumienia tego pojęcia.

Analizujac zaakceptowane w orzecznictwie definicje i przesłanki stwierdzenia obejścia prawa, można zauważyć pewną niekonsekwencję. Powszechnie używana w orzecznictwie definicja obejścia prawa, zgodnie z która celem czynności mającej na celu obejście prawa jest osiagnięcie skutku zakazanego przez prawo, oznacza, że obejście prawa jest formą sprzeczności z prawem. Należy zauważyć, że nie ma korelacji między tą definicją a stosowanymi w orzecznictwie przesłankami obejścia ustawy. Opieranie się na tej definicji sprzyja potocznemu rozumieniu obejścia prawa i jego stwierdzaniu w przypadku sprzeczności z prawem czy zasadami współżycia społecznego. Trafniejsza wydaje się definicja Trzaskowskiego, która opiera się na założeniu, że rezultat czynności mającej na celu obejście ustawy nie jest przez ustawę zakazany, ale obchodzona norma prawna ma mu zapobiec ${ }^{52}$.

\section{Autonomiczność konstrukcji obejścia prawa}

$\mathrm{W}$ orzecznictwie $\mathrm{i} \mathrm{w}$ literaturze przedmiotu nie jest podawane $\mathrm{w}$ watpliwość, że czynność mająca na celu obejście ustawy nie jest czynnością pozorna, czynnością sprzeczną z zasadami współżycia społecznego, czynnością sprzeczną z naturą umowy i stanowiąca nadużycie prawa. Kwestionowana jest natomiast autonomiczność obejścia prawa w stosunku do sprzeczności z prawem.

Sądy odróżniają czynności prawne in fraudem legis od czynności prawnych contra legem ${ }^{53}$. Praktyka orzecznicza wskazuje na inne przesłanki orzekania

52 Trzaskowski (2014): 441.

${ }^{53}$ Np. wyroki SN: z 22 grudnia 1970 r., II CR 517/70, Lex nr 6841; z 27 czerwca 2001 r., II CKN 602/00, Lex nr 49119; z 2 lipca 2008 r., II UK 334/07; z 17 czerwca 2011 r., II CSK 620/10, Lex nr 846567; z 27 czerwca 2013 r., I UK 10/13, Lex nr 1391149; z 30 września 2016 r., I CSK 858/14, Lex nr 2152382 . 
sprzeczności z prawem i jego obejścia. W konsekwencji gdy czynność prawna spełnia przesłanki obejścia prawa, sądy stwierdzaja, że została ona dokonana w celu obejścia ustawy. Przykłady takich orzeczeń wskazałam powyżej. Jednak na próżno szukać w orzecznictwie sądowym pogłębionej analizy kwestii autonomiczności konstrukcji obejścia prawa.

W literaturze przytoczono argumenty za uznaniem czynności mającej na celu obejście ustawy za odrębną konstrukcję prawną. Pierwsza grupa argumentów opiera się na treści art. 58 § 1 k.c., który stanowi, że „[c]zynność prawna sprzeczna z ustawą albo mająca na celu obejście ustawy jest nieważna, chyba że [...]"54. Wymienienie w jednym przepisie obu - czynności prawnej in fraudem legis i czynności contra legem - świadczy według Stanisława Rudnickiego o tym, że są to dwa różne stany prawne ${ }^{55}$. Ogólne zasady wykładni prawa dostarczaja dodatkowych argumentów na poparcie tej tezy, w tym zasada, że różnym zwrotom nie należy nadawać tego samego znaczenia. Jak podkreślił SN, posłużenie się przez ustawodawcę spójnikiem ,albo” oznacza, że przedstawił on dwie wyłączające się podstawy uznania czynności prawnej za nieważną ${ }^{56}$. Także założenie o racjonalności prawodawcy sprzyja tej tezie. Marek Safjan zauważa, że zatarcie różnic między tymi zwrotami oznaczałoby „skrajną nieracjonalność ustawodawcy" 57 . Ponadto zaprzeczałoby to założeniu, że prawodawca nie stanowi norm zbędnych i zna znaczenie słów, których używa.

Krytycy powoływania się na treść art. 58 k.c. w celu uzasadnienia tezy o autonomiczności konstrukcji obejścia prawa podnosza, że argumenty te można potraktować jako próbę nadania sensu obecnemu brzmieniu tego przepisu.

Druga grupa argumentów za autonomicznością konstrukcji obejścia prawa odwołuje się do praktyki stosowania prawa. Piotr Karwat zauważa, że czynności prawne mające na celu obejście ustawy, w odróżnieniu od czynności sprzecznych z ustawa, mają cechy nietypowe i sztuczne ${ }^{58}$. Wojciech Wasowicz wskazuje, że w braku regulacji obejścia prawa w przypadkach, w których wykładnia rozszerzająca nie mogłaby być zastosowana, nie byłoby możliwości uznania czynności prawnej mającej na celu obejście ustawy za nieważna ${ }^{59}$. Ponadto można wskazać, że specyfika obejścia ustawy jest to, że w zdecydowanej większości przypadków obejścia prawa dopiero zbadanie okoliczności dokonania łańcucha różnych czynności prawnych łącznie może zdemaskować prawdziwy cel stron tych czynności, którym jest obejście ustawy.

W orzecznictwie sądów polskich obejście prawa jest konstrukcją autonomiczna w stosunku do innych konstrukcji prawa prywatnego. Wypełnia ona lukę, która istnieje (albo może istnieć) między zakresem zastosowania sprzeczności z prawem i zakresem zastosowania sprzeczności z zasadami współżycia

${ }^{54}$ Także Trzaskowski twierdzi, że „chodzi tu o autonomiczna konstrukcję art. $58 \S 1$ ”. Dodaje jednak, że „[t]ak pojmowane obejście prawa może być zakwalifikowane jako przypadek szeroko rozumianej, dwustronnej sprzeczności zawarcia umowy z prawem” - Trzaskowski (2002): 441.

${ }_{55}$ Dmowski, Rudnicki (2011): 270; Stawecki (2003): 90.

${ }^{56}$ Wyrok SN z 21 lipca 2004 r., V CK 21/04, Lex nr 141168.

${ }^{57}$ Safjan (2018): 298.

${ }^{58}$ Karwat (2002): 30.

${ }^{59}$ Wąsowicz (1999): 81. 
społecznego. Obejście prawa powinno być bowiem stwierdzane tylko wtedy, gdy nie można stwierdzić sprzeczności z normą prawną wyinterpretowana $\mathrm{w}$ drodze zastosowania wykładni funkcjonalnej lub systemowej przepisu ustawy albo zastosowania go w drodze analogii. Dlatego zakres zastosowania konstrukcji obejścia prawa zależy od sposobu zdefiniowania reguły odstępstwa od sensu językowego przepisu lub jego części. Wąskie sformułowanie przypadków, w których dopuszczalne jest przełamanie rezultatów wykładni językowej, spowodowałoby częstsze stosowanie konstrukcji obejścia prawa. Natomiast szerokie sformułowanie takich przypadków prowadzi do rozwijania prawa przez odchodzenie od jasnego i oczywistego sensu językowego przepisu prawnego i zmarginalizowania potrzeby wyróżniania obejścia prawa. Jednakże nawet $\mathrm{w}$ tym przypadku nie pozbawia to konstrukcji obejścia prawa jej autonomiczności.

\section{Funkcja regulacji zakazu dokonywania czynności prawnych mających na celu obejście ustawy}

W literaturze przyjmuje się, że funkcja regulacji zakazu obejścia prawa sprowadza się do zwrócenia uwagi „na konieczność rozwijania w drodze wykładni funkcjonalnej przepisów i norm prawnych dla zrekonstruowania obowiąującego systemu prawnego”, do „rozstrzygnięcia kwestii celu czynności jako kategorii służącej do oceny ważności czynności prawnej”60, czy do przecięcia sporu dotyczącego skutków prawnych obejścia prawa ${ }^{61}$. Analiza orzecznictwa sądów polskich pozwala na wyróżnienie dalszych funkcji omawianego zakazu.

Niewątpliwie zakaz obejścia ustawy jest jednym z narzędzi umożliwiających sędziom wydanie sprawiedliwego orzeczenia, także jeżeli uznają że w okolicznościach sprawy inne przepisy prawne nie maja zastosowania. Dodatkowo regulacja zakazu obejścia prawa pozwala sędziom na reagowanie na nowe lub unikalne czynności prawne, których ustawodawca nie przewidział albo nie uregulował, a które służą obejściu ustawy. Orzekanie obejścia prawa w unikalnych stanach faktycznych pozwala sądom wpływać na rozwój prawa stanowionego, który jest inspirowany także ich decyzjami.

Ze względu na to, że rezultatem obejścia ustawy jest ominięcie zastosowania przepisów, które zasadniczo nie powinny być interpretowane w sposób rozszerzający ani stosowane przez analogię, orzeczenie sprzeczności z prawem $\mathrm{w}$ takich przypadkach mogłoby spotkać się z zarzutem dowolności stosowania prawa przez sądy. Ponadto orzeczenie sprzeczności z prawem czynności prawnej przez zastosowanie dyrektyw wykładni albo analogii nie pozwala zazwyczaj na uwzględnienie stanów podmiotowych stron. Brak możliwości stwierdzenia obejścia prawa w razie istnienia uzasadnionej przesłanki potwierdzającej konieczność dokonania kwestionowanej czynności prawnej (czy braku istnienia zamiaru i świadomości stron tej czynności) zwiększa elastyczność stosowania

${ }^{60}$ Grzybowski (1985): 516.

${ }^{61}$ Piekarski (1985): 254. 
prawa. Biorąc pod uwagę złożoność systemu prawnego, szczegółowość przepisów prawa i kontrowersje związane z zakresem zastosowania niektórych z nich, wydaje się, że należy dopuścić wyjątek od zasady zakazującej premiowania nieznajomości prawa, jeżeli tylko jednym z wielu skutków dokonania łańcucha czynności prawnych przez podmioty niemające zamiaru ani świadomości obejścia prawa byłby rezultat, któremu prawo miało zapobiec.

\section{PODSUMOWANIE}

Można oszacować, że w ciagu ostatnich 30 lat tylko w kilkuset sprawach Sąd Najwyższy uznał czynność prawną za mającą na celu obejście ustawy. W części tych spraw ta kwalifikacja prawna nie była poprawna. W zdecydowanie większej liczbie spraw obejście prawa zostało rozważone jako alternatywa dla ostatecznie zastosowanej kwalifikacji prawnej (np. pozorności czy sprzeczności z zasadami współżycia społecznego). Analiza tego orzecznictwa pozwala na stwierdzenie, że chociaż w doktrynie przeważa stanowisko, że czynności prawne mające na celu obejście ustawy stanowią kategorię czynności prawnych sprzecznych z ustawa, to w orzecznictwie sądów polskich jest to konstrukcja autonomiczna, która pełni istotne funkcje.

Dorota Miler

Uniwersytet w Augsburgu, Niemcy

dorota.miler@jura.uni-augsburg.de

https://orcid.org/0000-0002-4634-7208

Brzeziński, B. (2004). Narodziny i upadek orzeczniczej doktryny obejścia prawa podatkowego. Przegląd Orzecznictwa Podatkowego 71(1): 7-13.

Dmowski, S., Rudnicki, S. (2011). Komentarz do Kodeksu cywilnego. Księga pierwsza. Część ogólna. Warszawa.

Grzybowski, S. (1974). System prawa cywilnego. Część ogólna. Wrocław-Warszawa-KrakówGdańsk.

Grzybowski, S. (1985). System prawa cywilnego. Część ogólna. Wrocław-Warszawa-KrakówGdańsk-モódź.

Grykiel, J., Lemkowski, M. (2010). Czynności prawne. Art. 56-81 KC. Komentarz. Warszawa.

Gutowski, M. (2007). Czynność prawna podjęta w celu przestępczym. Glosa. Monitor Prawniczy 18: $1023-1026$.

Janas, A. (2017). Komentarz do art. 58, [w:] M. Habdas, M. Fras (red.), Kodeks cywilny. Komentarz. Tom 1: Część ogólna (art. 1-125). Warszawa: 485-518.

Janiak, A. (2012). Komentarz do art. 58, [w:] A. Kidyba, Kodeks Cywilny. Komentarz Lex. Tom 1: Część ogólna. Warszawa: 334-360.

Kalinowski, M. (2004). Glosa do Wyroku Składu Siedmiu Sędziów Naczelnego Sądu Administracyjnego z dnia 24 listopada 2003 r. FSA 3/03. Orzecznictwo Sądów Polskich 6: 306-309.

Kalinowski, M. (2001). Granice legalności unikania opodatkowania w polskim systemie podatkowym. Toruń.

Karwat, P. (2002). Obejście prawa podatkowego. Warszawa.

Księżak, P. (2014). Komentarz do art. 58, [w:] M. Pyziak-Szafnicka, P. Księżak (red.), Kodeks cywilny. Część ogólna. Warszawa: 641-672. 
Machnikowski, P. (2013). Treść umowy, [w:] E. Łętowska (red.), System prawa prywatnego. Tom 5: Prawo zobowiązań - część ogólna. Warszawa: 503-587.

Morawski, L. (2011). Zasady wykładni prawa. Toruń.

Olejniczak, A. (2019). System prawa prywatnego. Prawo cywilne - część ogólna. Warszawa.

Piekarski, M. (1985). Przepisy ogólne o czynnościach prawnych. Nowe Prawo 3(225): 251-257.

Radwański, Z., Trzaskowski, R. (2019). Treść czynności prawnej, [w:] A. Olejniczak, System prawa prywatnego. Tom 2: Prawo cywilne - część ogólna. Warszawa: 303-366.

Safjan, M. (2018). Komentarz do art. 58, [w:] K. Pietrzykowski (red.), Kodeks cywilny. Tom 1: Komentarz. Art. 1-49910. Warszawa: 288-310.

Stawecki, T. (2003). Obejście prawa. Szkic na temat granic prawa i zasad jego wykładni, [w:] H. Izdebski, A. Stępkowski (red.), Nadużycie prawa. Warszawa: 87-110.

Tracz, G., Zoll, F. (1996). Przewłaszczenie na zabezpieczenie. Kraków.

Trzaskowski, R. (2002). Zasada swobody umów w orzecznictwie sądowym, część druga. Przegląd Sądowy 12(5): 116-152.

Trzaskowski, R. (2014). Komentarz do art. 58, [w:] J. Gudowski (red.), Kodeks cywilny. Komentarz. Warszawa: 408-543.

Vidal, J. (1957). Essai d'une théorie générale de la fraude en droit français, le principe efraus omnia corrumpite. Toulouse.

Wawrzyńczak, R. (1985). O pewnym modelu działania i dwu jego aplikacjach. Wrocław.

Wąsowicz, W. (1999). Obejście prawa jako przyczyna nieważności czynności prawnej. Kwartalnik Prawa Prywatnego 8(1): 69-95.

Wolter, A. (2001). Prawo cywilne. Zarys części ogólnej. Warszawa.

Zieliński, M., Radwański, Z. (2006). Wykładnia prawa cywilnego. Studia Prawa Prywatnego 1(1): $1-40$.

Zieliński, T. (1967). Nieważność czynności sprzecznych z ustawą w prawie cywilnym. Ruch Prawniczy, Ekonomiczny i Socjologiczny 29(2): 69-85.

\section{LEGAL TRANSACTIONS AIMED AT CIRCUMVENTING STATUTORY LAW IN THE CONTEXT OF THE CASE-LAW OF POLISH COURTS}

\section{Sum mary}

The position that legal transactions which circumvent an act of statutory law constitute a category of legal transactions contrary to the law prevails in the legal literature. However, Polish jurisprudence has not entirely followed this view. In some judgments, courts have distinguished transactions circumventing the law from other legal constructions, including transactions contrary to the law. In the article, the definition of law circumvention, the prerequisites for finding law circumvention, and examples of transactions aimed at circumventing statutory law identified in Polish jurisprudence are presented and discussed. The issue of autonomy and the functions performed by the prohibition on circumventing an act of statutory law in Polish private law in the context of the judgments of Polish courts is discussed in the conclusions. The author believes that law circumvention is autonomous from other private law constructions. It is a legal construction that fills a gap existing between the scope of application of a legal contradiction with the law and the scope of a contradiction with the principles of community life. The scope of the application of the construction of law circumvention depends on the definition of the rule of departure from the linguistic meaning of a legal provision or its part. An analysis of Polish case law allows identification of the important functions performed by the prohibition of transactions aimed at circumventing the law.

Keywords: law circumvention; circumvention of the law; circumvention of statute; contradiction with the law; jurisprudence; interpretation 